\title{
High Levels of Expression of the Tumor Suppressor Gene APC during Development of the Rat Central Nervous System
}

\author{
Ratan V. Bhat, Jay M. Baraban, Richard C. Johnson, Betty A. Eipper, and Richard E. Mains \\ Departments of Neuroscience, Psychiatry, and Behavioral Science, Johns Hopkins University School of Medicine, \\ Baltimore, Maryland 21205
}

\begin{abstract}
The adenomatous polyposis coli (APC) gene is a tumor suppressor gene that is mutated in human familial adenomatous polyposis, an autosomal dominant condition with predisposition to colorectal carcinoma and brain tumors. Although tumor suppressor genes appear to play a general role in regulating cellular proliferation, the normal biological function of the APC gene product is unknown. In the present study, we cloned fragments of the rat homolog of the APC gene and examined its tissue distribution by Northern blot analysis. These studies demonstrated particularly high levels of APC mRNA in brain. To gain clues to the role of the APC gene in brain function, we examined the neuroanatomical distribution of APC mRNA using in situ hybridization. In the adult, prominent expression of APC mRNA was observed in the olfactory bulb, hippocampus, and cerebellum, with low levels of hybridization in other regions of adult rat brain. In contrast, during embryonic and early postnatal development (1-2 weeks), high levels of APC expression were found throughout the brain and then decreased to adult levels by 6 weeks after birth, except in the olfactory bulb where the high levels of APC mRNA found in development persist in the adult. During development of cortex, cerebellum, and retina, APC mRNA expression was particularly prominent in layers containing newly formed postmitotic neurons, with lower levels observed in the proliferative zones where neurogenesis occurs. The high levels of APC expression from early neurogenesis until late stages of neuronal maturation suggest that APC may contribute to suppressing neuronal proliferation during this period of intense growth.
\end{abstract}

[Key words: familial polyposis, tumor suppressor genes, in situ hybridization, differentiation, prohormone convertase, olfactory bulb]

Studies of genetic abnormalities in a wide spectrum of tumors have recently led to the identification of a class of genes, referred to as tumor suppressor genes (Klein, 1987; Weinberg, 1991). The association between deletions or mutations in these genes and tumorigenesis provides support for the hypothesis that un-

Received June 14, 1993; revised Oct. 28, 1993; accepted Nov. 1, 1993.

We thank Z. Garrett for excellent secretarial assistance and W. Kaufmann for technical advice. This work was supported by U.S. Public Health Service Grants DA-00266 (R.E.M., B.A.E., J.M.B.), DA-00097 (R.E.M.), DA-00098 (B.A.E.), DA-00525 (R.V.B.), and MH-00926 (J.M.B.).

Correspondence should be addressed to Richard E. Mains, Ph.D., Department of Neuroscience, WBSB 907, Johns Hopkins University School of Medicine, 725 North Wolfe Street, Baltimore, MD 21205-2185.

Copyright (c) 1994 Society for Neuroscience $0270-6474 / 94 / 143059-13 \$ 05.00 / 0$ der normal conditions members of this class, such as the retinoblastoma (RB), p53, deleted in colon cancer (DCC), Wilms tumor (WT1), and neurofibromatosis type 1 (NF1) genes, regulate cellular proliferation and differentiation (Klein, 1987; Sager, 1989; Weinberg, 1991; Vogelstein and Kinzler, 1993).

Familial adenomatous polyposis (FAP) is an autosomal dominant condition associated with germline mutations in a tumor suppressor gene referred to as APC (adenomatous polyposis coli); mutations in the APC gene predispose young adults to develop multiple adenomatous polyps in the colon and eventually malignant colorectal tumors (Herrera et al., 1986; Groden et al., 1991; Joslyn et al., 1991; Kinzler et al., 1991; Nishisho et al., 1991; Miyoshi et al., 1992). An inherited predisposition to multiple intestinal neoplasia in mice has also been linked to a mutation in the murine homolog of the APC gene (Su et al., 1991). In addition, APC gene nutations also appear to be an early event in the development of sporadic colorectal neoplasms (Powell et al., 1992). The effects of germline APC mutations do not appear to be restricted to the colon, since many extracolonic manifestations of FAP have been reported, including an association between FAP and tumors of the CNS, referred to as Turcot's syndrome (Crail, 1949; Turcot et al., 1959; Kropilak et al., 1989; Sohrabi et al., 1991). Furthermore, PCR-based analysis of various human tissues indicates that APC expression is not limited to the colon but also occurs in brain, lung, aorta, spleen, and placenta (Groden et al., 1991). Thus, the APC gene may be involved in regulating cellular proliferation in a wide variety of tissues, including brain.

The APC gene encodes a hydrophilic $312 \mathrm{kDa}$ protein with no obvious signal peptide or membrane-spanning domains and no striking homology to proteins of known function (Groden et al., 1991; Kinzler et al., 1991; Smith et al., 1993). Although the association between mutations in the APC gene and FAP supports a role for this gene in suppressing oncogenesis, little is known about its normal cellular function. While screening a rat hypothalamic cDNA library at low stringency for novel brainspecific subtilisin-like prohormone convertases involved in neuropeptide biosynthesis, we cloned a cDNA corresponding to an mRNA expressed at high levels in the CNS. Further analysis demonstrated that this sequence was highly homologous with the human APC gene. To help decipher the normal biological function of the APC gene in the CNS, we examined the anatomical distribution of its mRNA using Northern blot analysis and in situ hybridization. In particular, since tumor suppressor genes act as negative regulators of cell proliferation, we have focused on defining APC gene expression in embryonic and early postnatal development. 


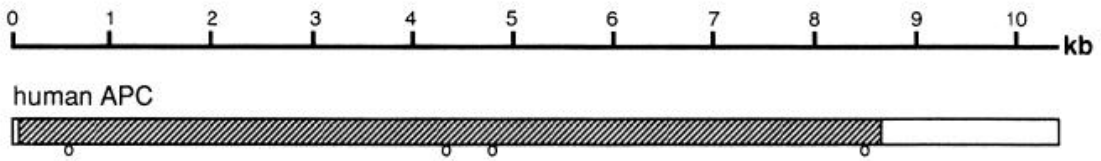

Figure 1. Rat APC cDNA. The human APC cDNA (M73548) is diagrammed, and the alignment of rat hypothalamic clone $\mathrm{X} 412$ is indicated. The restriction sites used to subclone regions of X412 are also indicated, along with the regions of X412 that were sequenced (solid bars). Regions of $\geq 30 \mathrm{nt}$ in length with $\geq 70 \%$ identity between human $\mathrm{APC}$ and rat PC1, PC2, or furin screening probes are indicated by an open circle. The partial sequence of X412 has been submitted to GenBank (accession \#L19294).

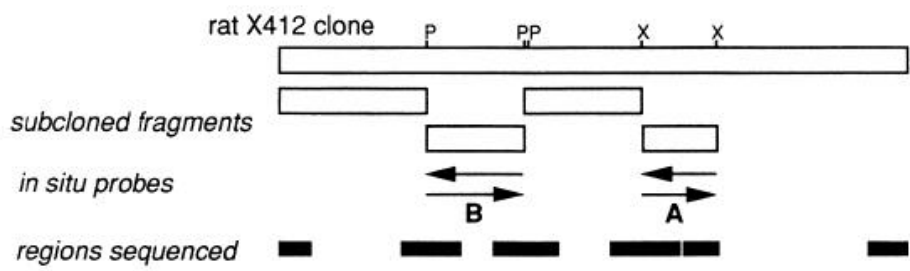

Restriction sites: $P=P s t ~ I$

mas Protein-coding

$X=$ Xhol

$0=>70 \%$ identity to screening probe

\section{Materials and Methods}

Cloning of rat $A P C C D N A$. A rat hypothalamic cDNA library (Lambda ZapII vector, Stratagene, La Jolla, CA; prepared as in Stoffers et al., 1989) was screened by plaque hybridization for additional members of the subtilisin family of peptide biosynthetic endoproteases using an equal mixture of three 450 nucleotide (nt) cDNA probes corresponding to portions of rat $\mathrm{PCl}$ (nt 1007-1451), rat PC2 (nt 1109-1556), and rat furin (nt 1187-1631) (Bloomquist et al., 1991). We used low-stringency screening conditions $\left[25^{\circ} \mathrm{C}, 50 \%\right.$ formamide, $0.75 \mathrm{M} \mathrm{NaCl}, 75 \mathrm{~mm}$ sodium citrate ( $\mathrm{pH} 7.0), 0.8 \mathrm{mg} / \mathrm{ml}$ Ficoll, $0.8 \mathrm{mg} / \mathrm{ml}$ polyvinylpyrrolidine, $0.8 \mathrm{mg} / \mathrm{ml}$ bovine serum albumin, $20 \mathrm{~mm}$ sodium phosphate, $0.1 \%$
SDS, $0.1 \mathrm{mg} / \mathrm{ml}$ sonicated herring sperm DNA] (Sambrook et al., 1989; Yoon et al., 1989; Tamkun et al., 1991). Southern blots were washed as described (Stoffers et al., 1989) except that the higher-stringency wash was at $37^{\circ} \mathrm{C}$ instead of $50^{\circ} \mathrm{C}$. Phages showing strong hybridization were plaque purified and inserts were rescued as pBluescript plasmids using helper phage. cDNA inserts were radiolabeled and used to probe Northern blots with RNA prepared from a variety of adult rat tissues; only cDNA inserts encoding neuroendocrine-specific transcripts were pursued. Since transcripts recognized by clone X412 were highly enriched in the CNS, its 6.2 kilobase $(\mathrm{kb})$ insert was partially sequenced; comparison to sequences in GenBank revealed that clone X412 was the rat homolog of mouse and human APC (Fig. 1). Four restriction fragments

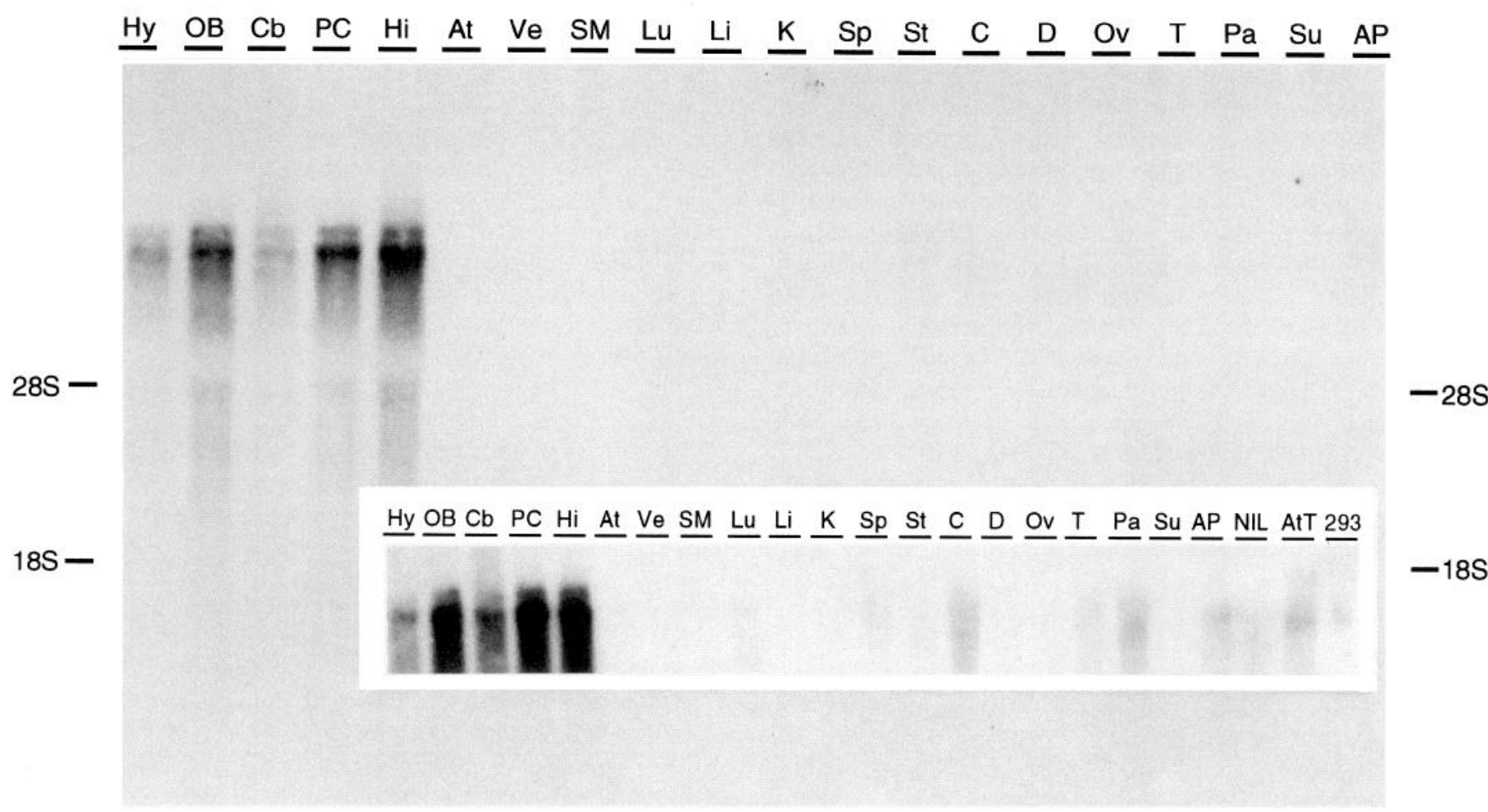

Figure 2. Northern blot analysis of APC mRNA in various adult rat tissues. Total RNA was prepared from various adult rat tissues and $10 \mu \mathrm{g}$ was separated on a denaturing gel and blotted. The positions of the $18 \mathrm{~S}$ and $28 \mathrm{~S}$ ribosomal RNAs, as detected with ethidium bromide, are indicated; ethidium bromide staining confirmed approximately equal loading of all the lanes (not shown) for this autoradiogram exposed for $5 \mathrm{~d}$. The inset shows a deliberate overexposure of the brain tissues on an independent Northern blot, to visualize the weak signals in several non-CNS tissues. Similar results were obtained in four independent analyses of this type using three independent sets of RNA from the various tissues. $H y$, hypothalamus; $O B$, olfactory bulb; $C b$, cerebellum; $P C$, parietal cortex; $H i$, hippocampus; $A t$, atrium; $V e$, ventricle; $S M$, skeletal muscle; $L u$, lung; $L i$, liver; $K$, kidney; $S p$, spleen; $S t$, stomach; $C$, colon; $D$, duodenum; $O v$, ovary; $T$, testis; $P a$, pancreas; $S u$, submaxillary; $A P$, anterior pituitary; NIL, neurointermediate pituitary; AtT, AtT-20 mouse corticotrope cells; 293, human embryonic kidney 293 cells. 

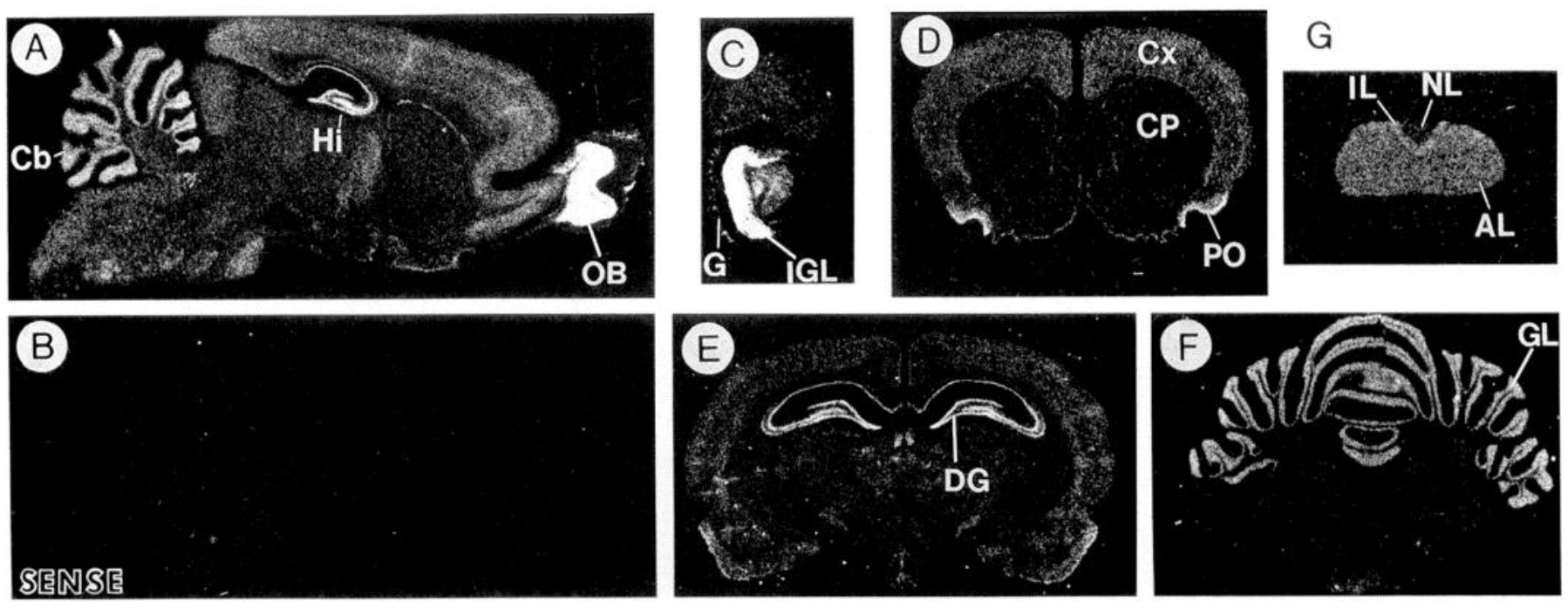

Figure 3. In situ localization of APC mRNA in adult rat brain. $A$, Sagittal section displays marked heterogeneity of APC expression with several areas of prominent hybridization, cerebellum $(\mathrm{Cb})$, hippocampus $(\mathrm{Hi})$, and olfactory bulb $(\mathrm{OB})$. B, Adjacent sagittal section hybridized with ${ }^{35} \mathrm{~S}$ labeled sense riboprobe demonstrates lack of signal. $C-G$, Coronal sections taken at the level of the olfactory bulb $(C)$, striatum $(D)$, hippocampus $(E)$, cerebellum $(F)$, and pituitary $(G)$. $G$, glomerular layer of olfactory bulb; $I G L$, internal granule layer; $C x$, cortex; $C P$, caudate putamen; $P O$, primary olfactory cortex; $D G$, dentate gyrus; $G L$, granule cell layer; $I L$, intermediate lobe of the pituitary; $N L$, neural lobe; $A L$, anterior lobe.
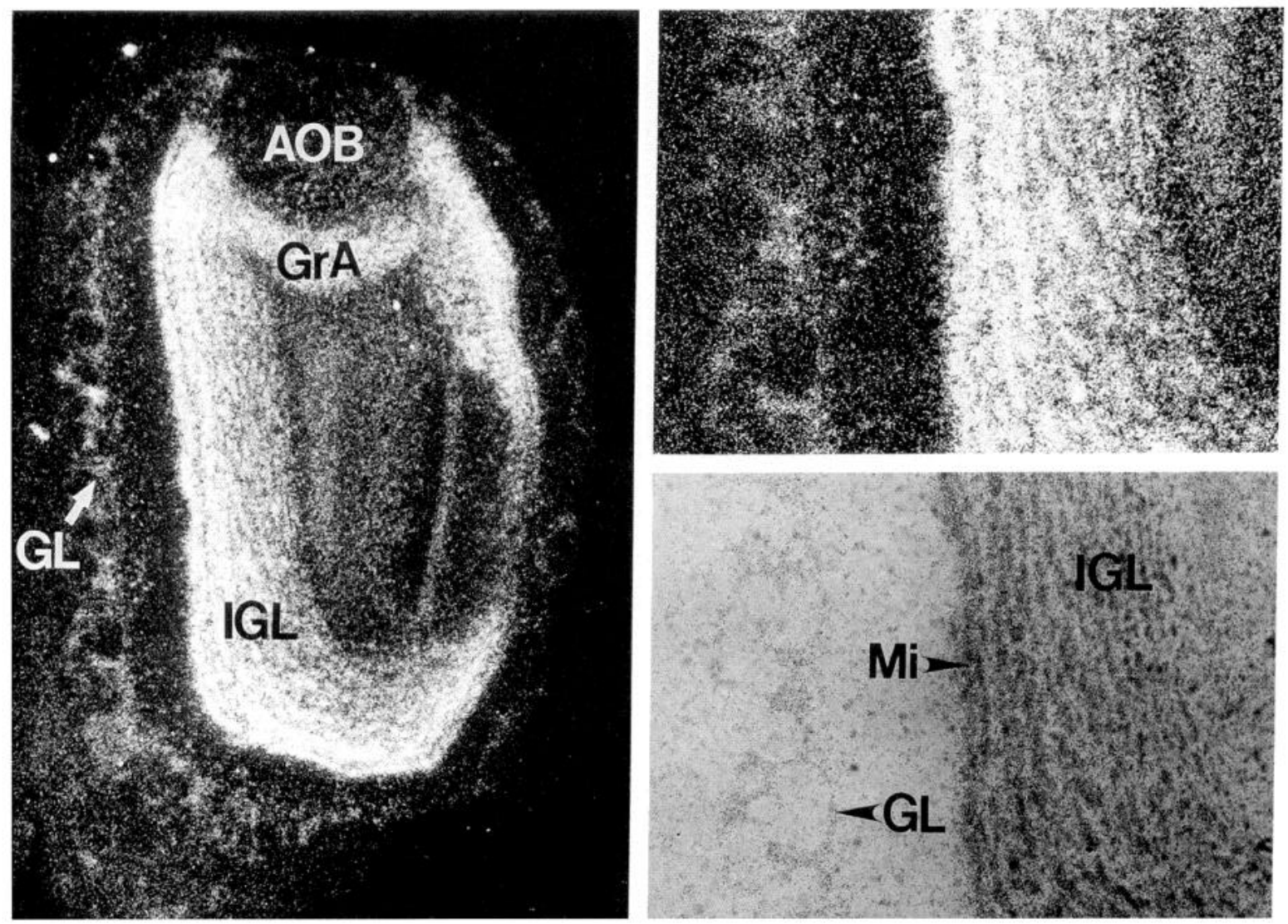

Figure 4. Expression of APC mRNA in adult olfactory bulb. Left panel represents a dark-field photomicrograph of an emulsion-dipped coronal section of adult rat olfactory bulb. Following in situ hybridization with ${ }^{35} \mathrm{~S}$-labeled APC antisense riboprobe, sections were coated with photographic emulsion as described under Materials and Methods. Top right shows higher magnification of the area enclosed. Exposure time was $2 \mathrm{~d}$. Bottom right is a bright-field photomicrograph of the same area, lightly counterstained with hematoxylin. $G L$, glomerular layer; $I G L$, internal granule layer; $G r A$, granule cell layer of accessory olfactory bulb; $A O B$, accessory olfactory bulb; $M i$, mitral cell layer. 

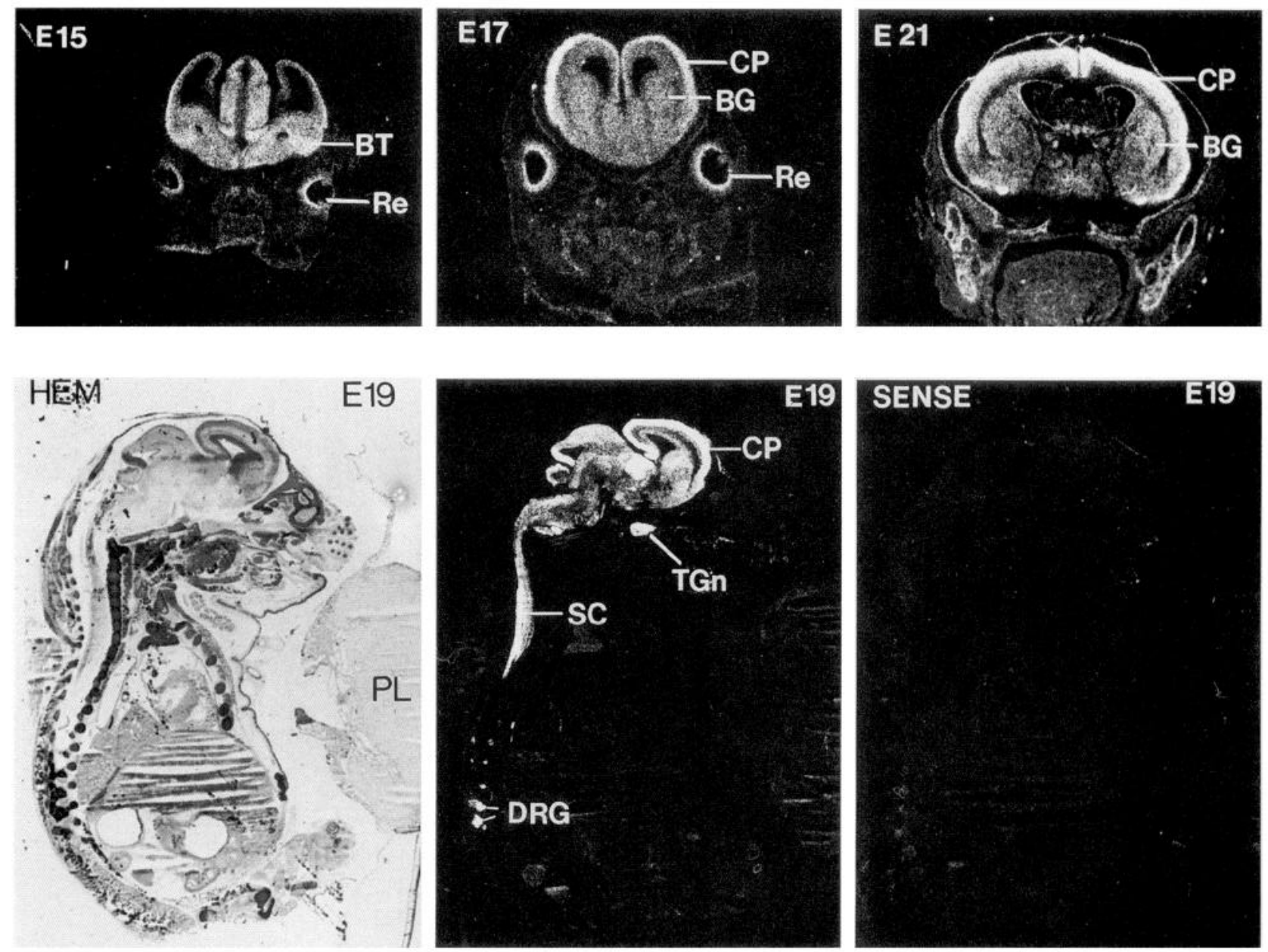

Figure 5. Expression of APC mRNA during embryonic development of the CNS. In situ autoradiograms of coronal sections hybridized with antisense APC riboprobe at E15, E17, and E21 are shown in top panels. Bottom panels show sagittal sections of the whole embryo at E19. Left panel of bottom row shows a bright-field photomicrograph of an E19 section counterstained with hematoxylin (HEM). Middle panel of bottom row shows in situ autoradiogram of the same section hybridized with antisense APC riboprobe. Right panel shows an adjacent section hybridized with sense APC probe. $B T$, basal telencephalon; $R e$, retina; $C P$, cortical plate; $B G$, basal ganglia; $P L$, placenta; $S C$, spinal cord; $T G n$, trigeminal ganglion; $D R G$, dorsal root ganglion.
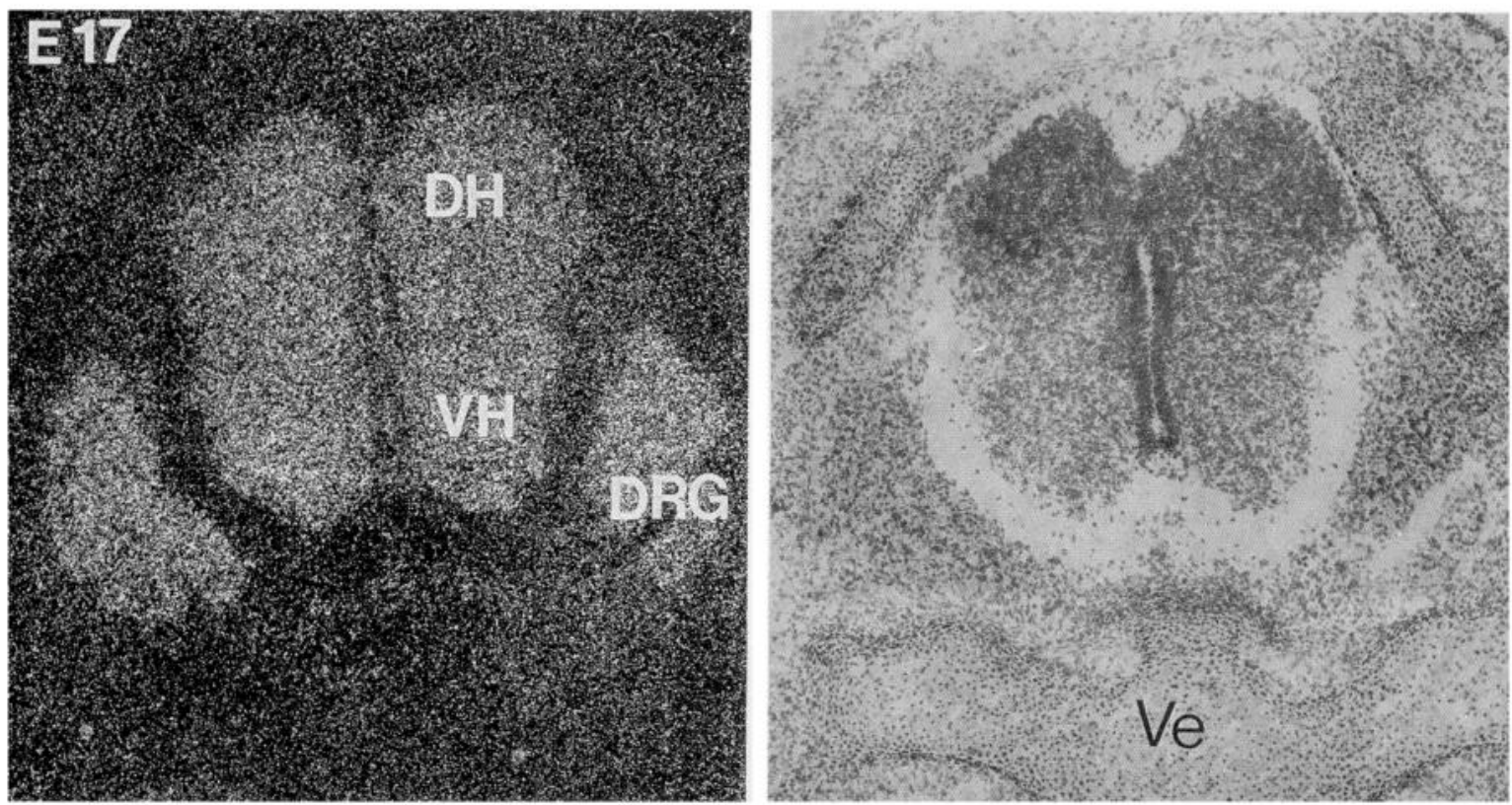
of X412 were subcloned into pBluescript (Stratagene) for sequencing, and two fragments (fragments A and B in Fig. 1) were used to prepare sense and antisense riboprobes for in situ hybridization analyses and cDNA probes for Northern blot analyses.

Animals. Sprague-Dawley rats (Harlan, Indianapolis, IN) were maintained in a light controlled room ( $12 \mathrm{hr}$ light/12 hr dark) with access to food and water ad libitum. Rats were designated as postnatal day 1 (P1) on the day of parturition. Pregnant female rats were staged based on presence of a vaginal plug.

Northern blot analyses. Tissues were dissected on ice and homogenized in guanidine isothiocyanate. Total cellular RNA was then isolated, separated by denaturing agarose gel electrophoresis, transferred to nylon membranes, hybridized, and washed under high-stringency conditions (Bloomquist et al., 1991). Subcloned fragments of rat APC (Fig. 1) were labeled by random priming using ${ }^{32} \mathrm{P}-\mathrm{dCTP} \alpha$.

In situ hybridization. In situ hybridization using ${ }^{35}$ S-labeled riboprobes was performed as previously described (Bhat et al., 1992). Whole embryos or brains were embedded in Tissue Tek (Miles, West Haven, CT) and rapidly frozen in plastic molds on a dry ice-ethanol slurry. Cryostat sections $12 \mu \mathrm{m}$ (Microm, Heidelberg, Germany) were mounted onto gelatin-coated slides. Slides were fixed in $4 \% \mathrm{w} / \mathrm{v}$ paraformaldehyde and acetylated with $0.5 \% \mathrm{w} / \mathrm{v}$ acetic anhydride in $0.9 \% \mathrm{w} / \mathrm{v} \mathrm{NaCl}$ containing $100 \mathrm{~mm}$ triethanolamine $(\mathrm{pH} 8.0),{ }^{35} \mathrm{~S}$-labeled riboprobe was added to the hybridization buffer containing $50 \%$ formamide, $600 \mathrm{~mm}$ $\mathrm{NaCl}, 1 \times$ Denhardt's, $10 \mathrm{~mm}$ Tris $\mathrm{HCl}(\mathrm{pH} 7.4), 1$ mм EDTA, $10 \mathrm{~mm}$ dithiothreitol, $0.2 \mu \mathrm{g} / \mu \mathrm{l}$ of tRNA, and $10 \%$ dextran to give a final concentration of $1 \times 10^{6} \mathrm{cpm} / 50 \mu \mathrm{l}$ of buffer. Hybridization was carried out overnight at $56^{\circ} \mathrm{C}$ in moist sealed chambers. Coverslips were removed under $2 \times \mathrm{SSC}(1 \times \mathrm{SSC}$ is $150 \mathrm{~mm} \mathrm{NaCl}, 15 \mathrm{~mm}$ sodium citrate, $\mathrm{pH}$ 7.0) at room temperature. Slides were incubated in a solution of $2 \times$ SSC $\left(30 \mathrm{~min}, 37^{\circ} \mathrm{C}\right.$ ) containing $10 \mu \mathrm{g} / \mathrm{ml}$ RNase A (Worthington, Freehold, NJ). The RNase treatment conditions for APC in situ hybridization were determined based on initial studies comparing hybridization with sense and antisense probes under different stringencies. Under the incubation conditions selected $\left(2 \times \mathrm{SSC}, 37^{\circ} \mathrm{C}\right)$, no hybridization signal was observed with the sense probes. At higher wash stringencies $(0.2 \times$ SSC, $37^{\circ} \mathrm{C}$ or $2 \times \mathrm{SSC}, 50^{\circ} \mathrm{C}$ ) the overall pattern of hybridization was identical, but the signal intensity with antisense probes was decreased slightly. After RNase treatment, slides were rinsed in $2 \times$ SSC at room temperature for an additional $30 \mathrm{~min}$, dehydrated in ethanol solutions, air dried, and exposed to $\mathrm{x}$-ray film (Kodak XAR) for 1-3 d. Experiments utilizing two different antisense riboprobes obtained from different regions of the rat APC gene (probes A and B, Fig. 1) yielded similar results. ${ }^{35}$ S-labeled sense and antisense riboprobes were transcribed from linearized plasmids using $T_{3}$ or $T_{7}$ RNA polymerase as described (Bhat et al., 1992). Hybridization with NMDA receptor probe NMDAR1 (gift from M. McLane, Zeneca, Wilmington, DE) was performed using similar conditions. For higher resolution analysis, slides were dipped in Kodak NTB2 photographic emulsion. After exposure for 3-7 d, slides were developed and lightly counterstained with hematoxylin. Anatomical structures were identified in conjunction with the atlases of Paxinos and Watson (1982) and Paxinos et al. (1991). To compare the intensity of hybridization during development, sections from animals of various embryonic and postnatal ages were processed for in situ hybridization together. The pattern of expression during development was examined in six developmental series. Each time point shown in the Results was represented in at least four of these series.

\section{Results}

\section{Cloning of rat $A P C C D N A$}

Clone X 412 was selected from a rat hypothalamic cDNA library based on two criteria: hybridization with a mixed cDNA probe specific for subtilisin-like endoproteases and expression limited to neuroendocrine tissues. However, examination of the sequence of X412 indicated that this clone did not exhibit any extended homology with domains conserved in other members of this protease family. Instead, a sequence homology search revealed that the nucleic acid sequence of clone $\mathrm{X} 412$ exhibits
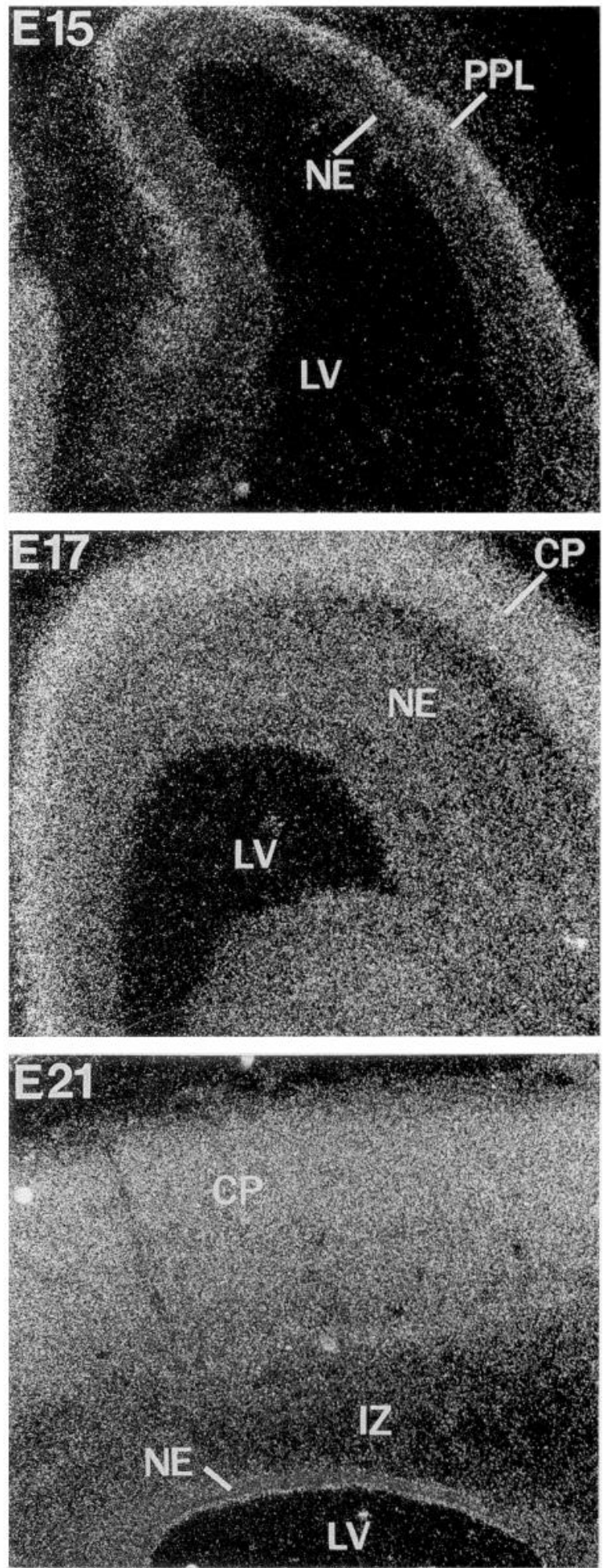

Figure 7. Expression of APC mRNA during embryonic development of the cortex. Panels show dark-field photomicrographs of photographic emulsion-dipped sections taken from developing cortex at E15 (top), E17 (middle), and E21 (bottom). Exposure time was 2 d. PPL, primordial plexiform layer; $N E$, neuroepithelium; $L V$, lateral ventricle; $C P$, cortical plate; $I Z$, intermediate zone.

Figure 6. Expression of APC mRNA in embryonic spinal cord and dorsal root ganglia. Transverse sections of E17 spinal cord were processed for APC in situ hybridization. Left panel shows a dark-field micrograph of an emulsion-dipped section; the right panel shows the same section counterstained with hematoxylin. $D H$, dorsal horn; $V H$, ventral horn; $D R G$, dorsal root ganglion; Ve, vertebrae. 

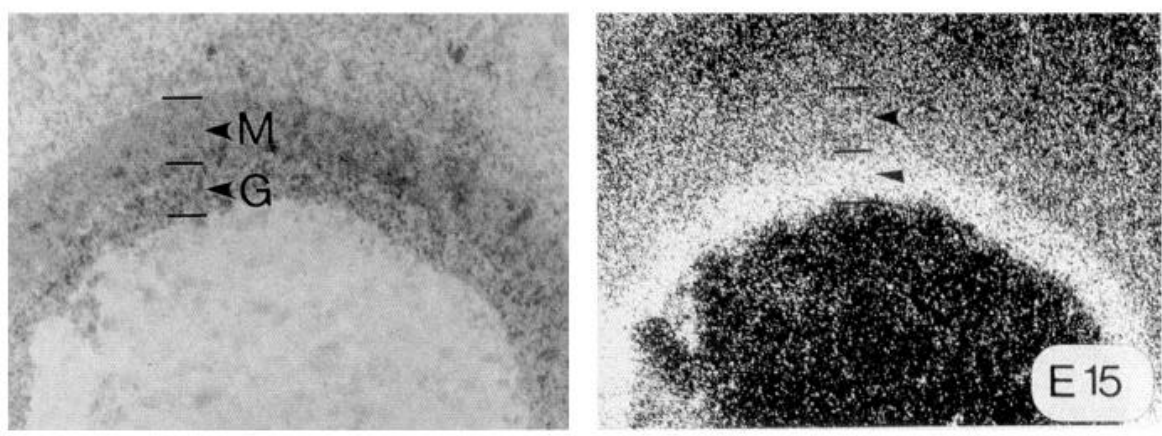

Figure 8. Expression of APC mRNA in the retina. Top panels show brightfield (left) or dark-field (right) photomicrographs of photographic emulsion-dipped sections of E15 retina. The neural retina is divided into two major layers: the layer closer to the vitreous, which develops into several layers including the ganglion cell layer $(G)$, and the outer layer or the matrix $(M)$. Bottom panels illustrate APC mRNA expression in adult $(A d)$ retina. $C T$, connective tissue; $P E$, pigment epithelium; $O S$, photoreceptor outer segments; $O N$ outer nuclei layer; $I N$, inner nuclear layer; $I P$, inner plexiform layer; $G C$, ganglion cell layer. Exposure time, $3 \mathrm{~d}$.
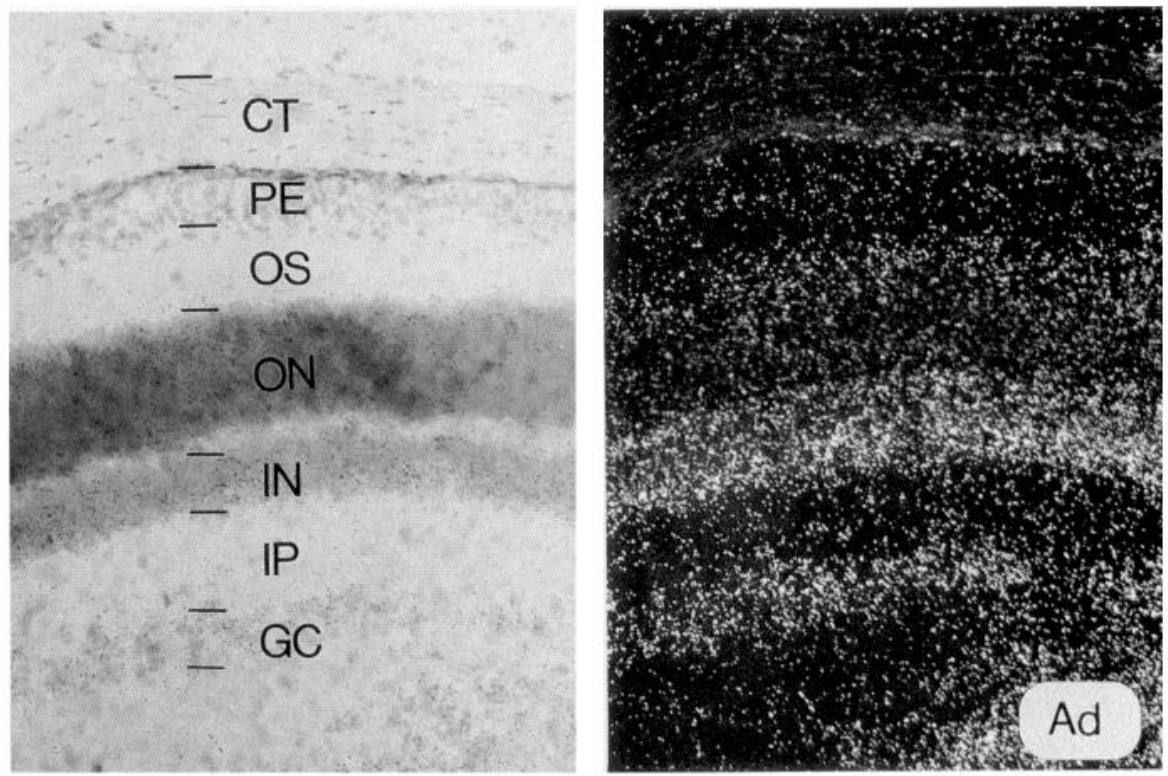

$\geq 95 \%$ identity with the corresponding sequences of the mouse and human APC genes (solid bars in Fig. 1). The $6.2 \mathrm{~kb}$ cDNA includes the $\mathrm{COOH}$-terminal half of the APC protein and most of the 3'-untranslated region, not including a polyA tail. The human APC cDNA (GenBank M73548) contains four regions of $\geq 30$ nt with $\geq 70 \%$ identity to the mixed PC1, PC2, and furin probe (indicated by circles in Fig. 1). Southern blot analyses of clone X412 demonstrated that the single restriction fragment containing two of these regions of homology was the only fragment that hybridized strongly with the mixed probe under the screening conditions used.

\section{Expression of rat APC $m R N A$ in adult tissues}

Northern blot analysis of a panel of adult rat tissues demonstrated a striking abundance of an approximately 9-10 kb APC mRNA in several brain regions (Fig. 2). Olfactory bulb, hippocampus, cerebellum, and parietal cortex contained the highest levels of APC mRNA. Much lower levels of APC mRNA were observed in the colon, pancreas and anterior pituitary. Two forms of APC mRNA ( $9 \mathrm{~kb}$ and $10 \mathrm{~kb}$ ) were observed in each of the tissues, perhaps due to alternative splicing as observed with the human APC gene (Groden et al., 1991). Longer exposure of a similar Northern blot revealed weak signals in several additional tissues (inset, Fig. 2). A similar distribution of APC mRNA was found using a panel of adult mouse tissues (not shown).

In situ hybridization of a sagittal section of adult rat brain revealed prominent expression of APC mRNA in the olfactory bulb, primary olfactory cortex, hippocampus, and cerebellum (Fig. 3A,C,D). Identical results were obtained with antisense probes prepared from either of two nonoverlapping regions of the cloned APC fragment. The lack of hybridization with the sense APC riboprobe confirmed the specificity of APC in situ hybridization (Fig. $3 B$ ). The neocortex showed a weak hybridization signal and levels of APC mRNA appeared to be extremely low in the adult caudate-putamen (Fig. 3D), thalamus, and spinal cord. The relatively strong signal observed for APC mRNA in parietal cortex based on Northern blot analysis may reflect normalization to ribosomal RNA. In the hippocampus, APC mRNA appears to be localized in the pyramidal neurons of CA1-CA4, as well as in dentate granule cells (Fig. $3 E$ ). In addition, hybridization was observed in the alveus, a fiber tract located at the edge of the hippocampus. In the cerebellum, hybridization was prominent in the granular layer (Fig. $3 F$ ). Low levels of APC mRNA expression were also observed in the anterior and intermediate lobes of the pituitary but not in the neural lobe of the pituitary (Fig. $3 G$ ).

Coronal sections through the olfactory bulb of adult rat brain were dipped in photographic emulsion and microscopic examination indicated that APC mRNA expression was most prominent in the internal granule and the mitral cell layers, as well as the granule cell layer of the accessory olfactory bulb (Fig. 4). Hybridization was also observed in cells surrounding the glomeruli. 

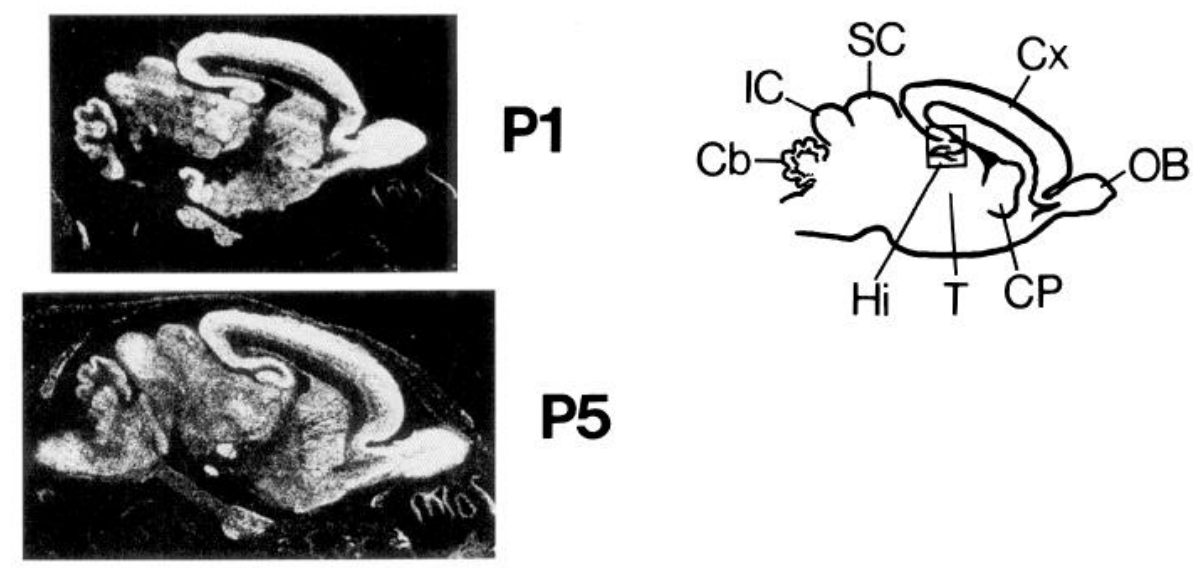

\section{P5}
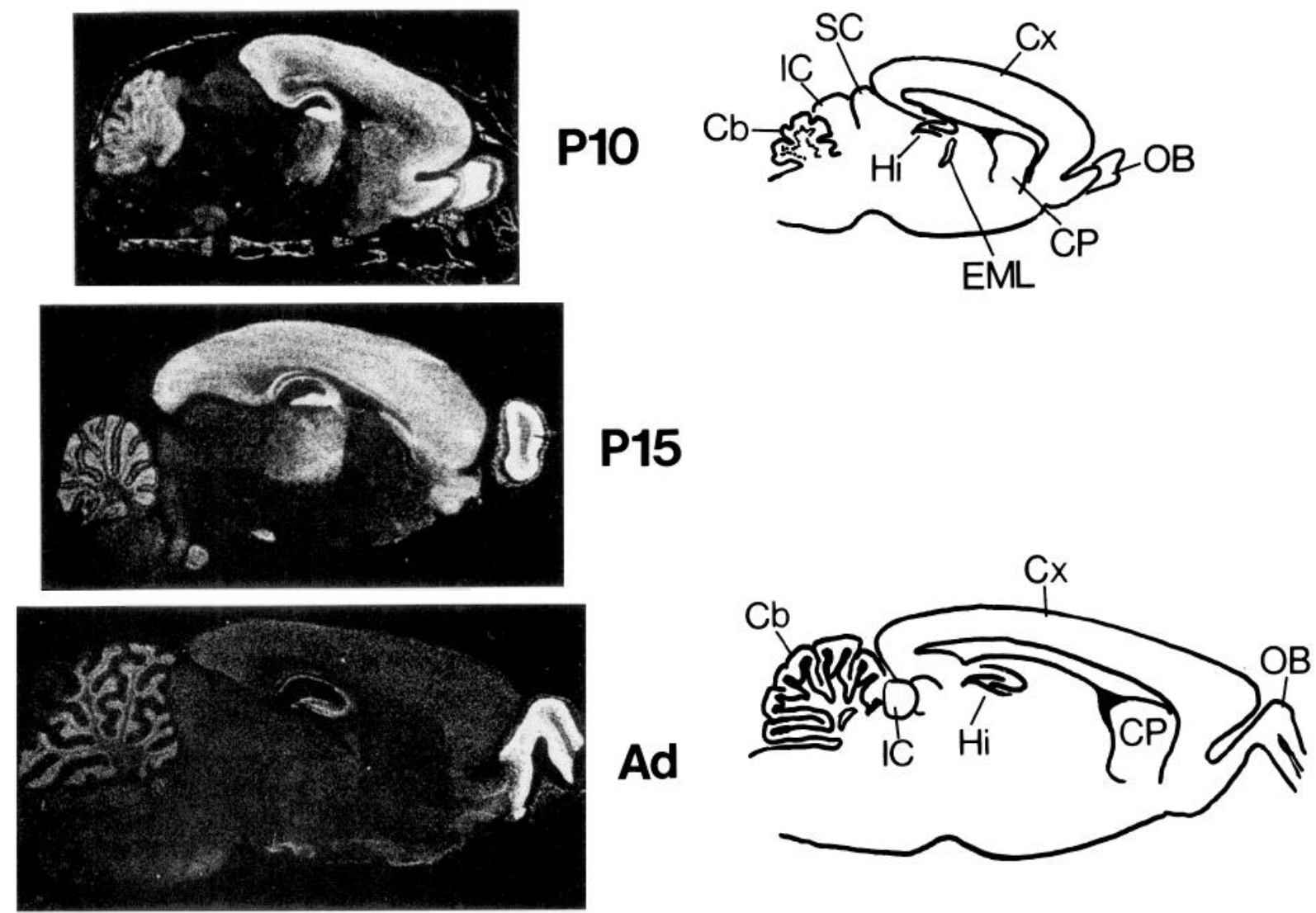

Figure 9. Developmental profile of APC mRNA distribution in postnatal rat brain: in situ autoradiograms of sagittal sections hybridized with antisense ${ }^{35} \mathrm{~S}$-labeled APC riboprobe taken from rats killed at indicated stages of development. Anatomical regions are depicted schematically to the right. Sections from different developmental stages were exposed to film for equal times. $C x$, cortex; $O B$, olfactory bulb; $C P$, caudate putamen; $T$, thalamus; $H i$, hippocampus; $C b$, cerebellum; $I C$, inferior colliculus; $S C$, superior colliculus; $E M L$, external medullary lamina.

\section{APC expression in embryonic development}

Since tumor suppressor genes are thought to regulate cellular proliferation and differentiation, we investigated the expression of APC mRNA during development of the CNS. Examination of in situ autoradiograms of sections through embryonic rat heads demonstrated that APC mRNA was expressed by embryonic day 15 (E15) in developing brain and retina (Fig. 5, top panels). Sagittal sections through the entire embryo at these developmental stages revealed that negligible levels of APC mRNA were found in tissues outside the central and peripheral nervous systems. Hybridization to an E19 section (Fig. 5, bottom panels) shows high levels of APC mRNA expressed in the brain and spinal cord. As in adult tissues, the sense riboprobe did not yield a hybridization signal. Microscopic examination of emulsion-dipped transverse sections of E17 spinal cord revealed intense hybridization in both spinal cord and dorsal root ganglia (Fig. 6). In comparable sections from the adult, APC hybridization was negligible (not shown).

Microscopic examination of photographic emulsion-dipped sections of E1 5 cortex demonstrated highest levels of APC mRNA in the outermost layer of the neuroepithelium, the primordial plexiform layer (Fig. 7, top). At E15, the primordial plexiform layer contains postmitotic cells that have migrated from the neuroepithelium and marks the future location of the cortical plate (Marin-Padilla, 1971; Konig and Marty, 1981). At E17, 


\section{APC Developmental Northern Analysis}

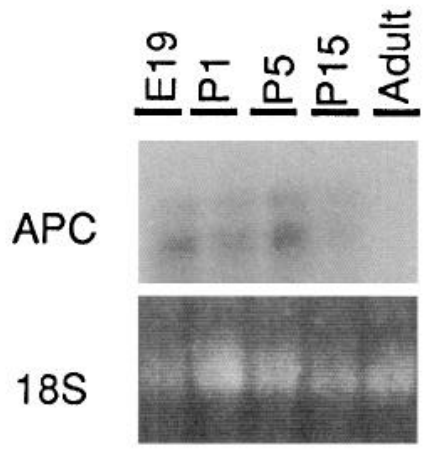

Figure 10. Northern blot analysis of APC mRNA during development. In the Northern blot shown each lane was loaded with $10 \mu \mathrm{g}$ of total RNA from the brains of animals killed at the indicated ages and hybridized with probe A. The portion of the blot containing the APC signal is shown in top panel. To keep the APC signal in the early postnatal samples from being overexposed in the analysis, the exposure time was only $12 \mathrm{hr}$. Ethidium bromide staining of the $18 \mathrm{~S}$ ribosomal RNA in the gel prior to transfer is shown in the bottom panel. Similar results were seen with a second independent developmental series of brain RNA sampleș.

APC mRNA was enriched in the cortical plate (Fig. 7, middle). At E21, as the cortical plate expands, APC mRNA expression remained uniformly high in this layer with much lower levels observed in the underlying neuroepithelium and intermediate zone (Fig. 7, bottom).

Microscopic examination of photographic emulsion-dipped sections of the developing retina also demonstrated marked heterogeneity of APC mRNA expression in this structure (Fig. 8). At E15, two major layers were apparent in the retina. In the matrix layer, which is analogous to the neuroepithelium of the cerebral cortex, neurons undergo their final division and then migrate inward toward the vitreous (Morest, 1970). This inner layer, which is analogous to the cortical plate, contains postmitotic neurons that eventually form the inner layers of the retina (Morest, 1970). These two layers are readily apparent in in situ autoradiograms using antisense APC riboprobes, as hybridization is markedly enriched in the inner layer containing postmitotic neurons. In the adult retina, APC mRNA expression was present at low levels in the ganglion cell and inner nuclear layers.

\section{APC expression in postnatal development}

High levels of APC mRNA persisted in the CNS during the first postnatal week and then declined over the next few weeks. The timing of this decline varied among regions and these differences are readily apparent in sagittal sections (Fig. 9). By P5, APC mRNA expression had diminished in the superior colliculus, and by P10 APC mRNA expression had diminished in the inferior colliculus and in the caudate putamen. However, in the cortex a decrease in APC mRNA expression was not apparent until 2 weeks after birth and levels of APC mRNA had not declined to adult levels until 6 weeks of age (Fig. 9). In striking contrast to the overall reduction of APC mRNA expression displayed throughout the brain, the extremely high levels of APC expression in the olfactory bulb persisted into adulthood.

The developmental profile of APC mRNA in the forebrain (excluding olfactory bulb) observed by in situ hybridization was confirmed by Northern blot analysis (Fig. 10). Two forms of APC mRNA ( $9 \mathrm{~kb}$ and $10 \mathrm{~kb}$ ) were consistently observed in the same proportion throughout development of the CNS, with highest levels observed between E19 and P5.

In the developing cerebellum, granule cells are generated in the external germinal layer (EGL) adjacent to the pial surface and then migrate past the Purkinje neuron cell bodies to reside in the internal granular layer (Miale and Sidman, 1961; Fujita et al., 1966; Altman, 1972; Jacobson, 1978; Burgoyne and Cambray-Deakin, 1988). Granule cells are thought to undergo their last division in the superficial layer of the EGL and then move to the adjacent deeper part of the EGL where they begin to put out processes prior to migrating to the internal granular layer. Microscopic examination of emulsion-dipped sections of the EGL at P5 (Fig. 11) revealed that APC mRNA hybridization was lower in the most superficial portion of the EGL than in deeper layers, indicating that APC mRNA expression is induced in postmitotic granule cells as they begin to migrate. At P15, APC hybridization was present in both the EGL and the internal granular layer. In the adult, expression persisted in the mature granule cells.

In the hippocampus, APC mRNA expression gradually declined over the course of development with reductions apparent even as late as 5-6 weeks after birth. Detailed examination of APC expression in this area revealed an unusual pattern of in situ hybridization (Figs. 12, 13). Prominent hybridization was observed in layers that correspond to two fiber tracts, the mossy fiber pathway and alveus extending into the fornix, in addition to the dentate granule cells and pyramidal neurons of the hippocampus. At later stages in development, APC mRNA expression in the mossy fiber pathway decreased and had disappeared by 6 weeks. Hybridization in the alveus persisted at reduced levels into adulthood (Fig. 13). To ensure that this unusual pattern of hybridization was not an artifact of the probe used, we confirmed that probes from two nonoverlapping regions yielded the same pattern. Furthermore, neither sense probe produced a hybridization signal. To assess whether this pattern of expression could be accounted for by hybridization to neuronal cell bodies, we performed in situ hybridization on adjacent sections with a probe to the NMDA receptor subunit NMDAR1. Previous in situ hybridization studies on the localization of NMDAR1 (Moriyoshi et al., 1991) demonstrated that NMDAR1 is expressed in neurons throughout the brain but not in white matter tracts. The NMDAR 1 probe did not hybridize to these fiber tract layers. (Fig. 13, top right).

In the thalamus, APC mRNA expression was widespread at $\mathrm{P} 1$ and P5. However, between P15 and P30, intense hybridization persisted only in the external medullary lamina, a white matter tract that courses between thalamic nuclei (Figs. 12, 13). By 6 weeks, APC expression in this layer was no longer apparent. Hybridization to this layer was not seen in adjacent sections processed for in situ hybridization with NMDAR 1 probe, indicating that the pattern of APC hybridization in the external medullary lamina does not reflect neuronal expression.

\section{Discussion}

The major finding of this study is that APC mRNA is expressed at high levels throughout the CNS during embryonic and early postnatal development. Analysis of the anatomical pattern of expression during development of several brain regions indicated that APC expression is induced soon after neurogenesis. In the cortex, neurons are generated near the ventricular surface 

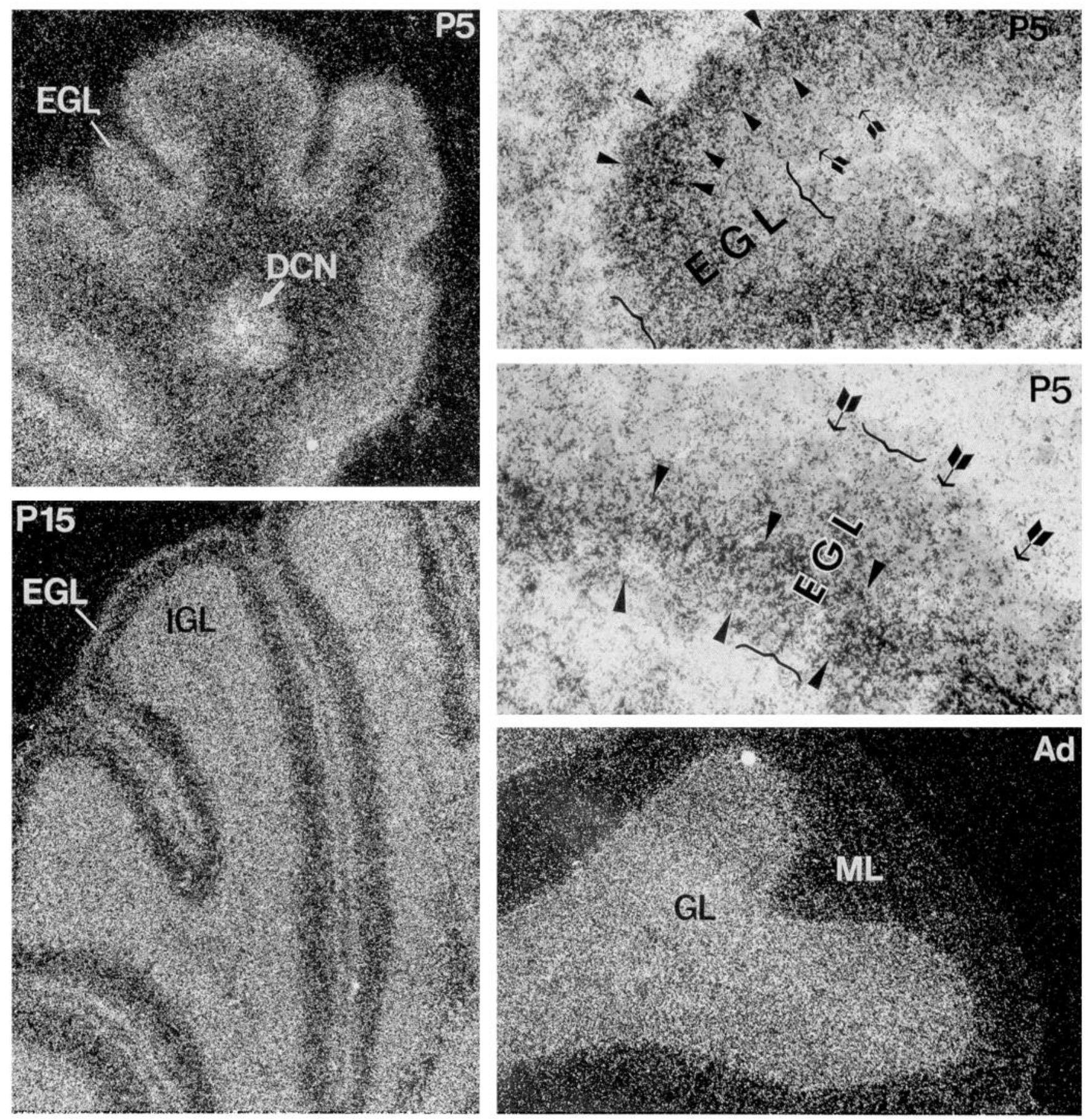

Figure 11. Expression of APC mRNA in postnatal development of cerebellum. In situ autoradiograms of sections hybridized with antisense APC riboprobe and coated with photographic emulsion, demonstrate APC mRNA in the cerebellum at P5, P15, and adult (Ad). To illustrate the localization of APC mRNA in the EGL at P5, high-power bright-field micrographs of hematoxylin-counterstained sections are shown (upper and middle right). The boundaries of the EGL are indicated by brackets. Arrowheads point to the inner layer of the EGL. The inner layer of the EGL contains a higher density of autoradiographic grains than the outer layer (bounded by arrows). Exposure time was $3 \mathrm{~d}$. EGL, external germinal layer; $D C N$, deep cerebellar nucleus; $G L$, granule cell layer; $M L$, molecular layer; $I G L$, internal granular layer.

and then migrate along radial glia to the cortical plate (Angevine and Sidman, 1961; Berry and Rogers, 1965; Rakic, 1972). Examination of APC expression in cortex during this period of neurogenesis demonstrates that expression is most prominent in the cortical plate. In the retina, the matrix zone, which contains the neuronal progenitor cells (Morest, 1970), had lower levels of APC mRNA expression than the adjacent layer to which differentiating postmitotic neurons of the inner retina migrate. Similarly, in the cerebellum, APC mRNA expression was lower in the superficial EGL than in the deeper layers, which contain postmitotic granule cells that are migrating to or have taken up residence in the internal granule layer. This pattern of APC mRNA expression in postmitotic cells is similar to that seen in the colonic epithelium, where APC immunostaining appears in epithelial cells as they migrate upward from the basal proliferative zone in the colonic crypts (Smith et al., 1993). This 

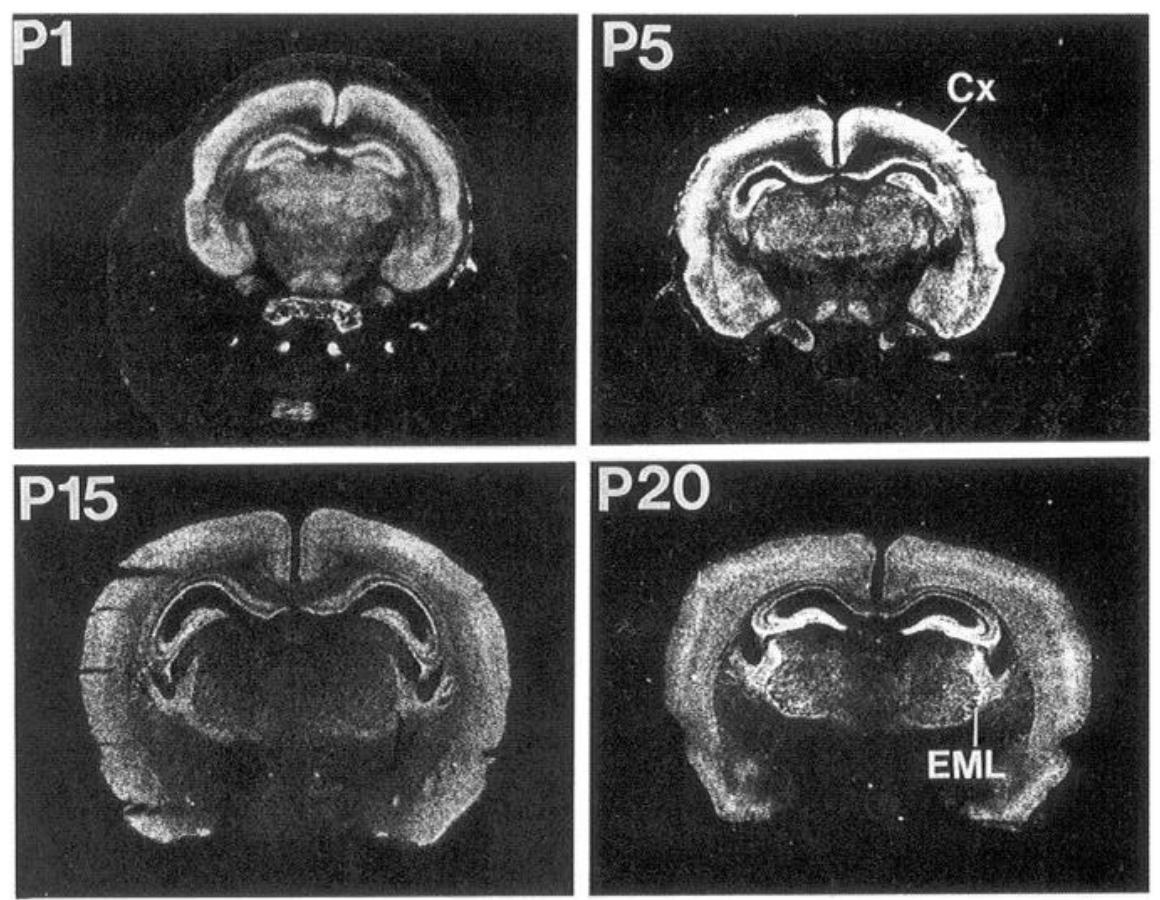

Figure 12. Localization of APC mRNA expression in forebrain during postnatal development: in situ autoradiograms of coronal sections hybridized with APC antisense riboprobe taken at the level of the hippocampus from animals killed at the indicated ages. $C x$, Cortex; $E M L$, external medullary lamina; $D G$, dentate granule cells of the hippocampus.
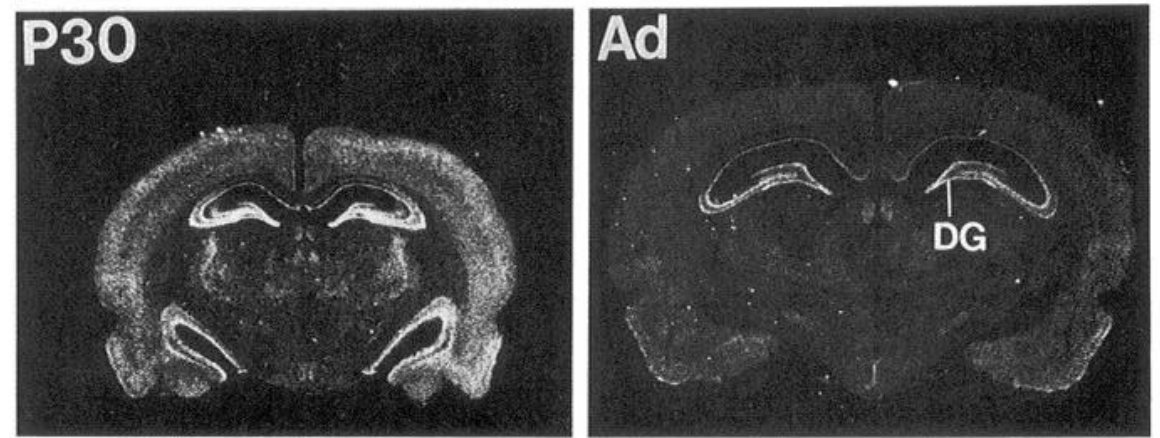

profile of APC expression suggests it is induced close to the time that cells become postmitotic. Conceivably, this tumor suppressor gene contributes to generating or maintaining the postmitotic state by limiting reentry into the cell cycle.

Recent studies provide evidence that other tumor suppressor genes may also play a role in neuronal development. Studies of RB-deficient mice reveal the presence of ectopic cells with mitotic figures in the cortex outside the ventricular zone, indicating that the RB gene may be important for preventing proliferation following migration (Lee et al., 1992). In addition, another tumor suppressor gene, DCC, is induced in $\mathrm{PC} 12$ cells following exposure to growth factors that promote differentiation (Lawlor and Narayanan, 1992). Furthermore, blockade of DCC expression prevents or reverses differentiation into the neuronal phenotype (Lawlor and Narayanan, 1992). Studies implicating another tumor suppressor gene, p53, in apoptosis (Clarke et al., 1993; Lowe et al., 1993) raises the intriguing possibility that the APC gene could also be involved in regulating programmed cell death in the developing CNS (Oppenheim, 1991). Although the role of the APC gene in neuronal development remains to be defined, it appears likely that it is one of several tumor suppressor genes that contribute to regulating the complex processes underlying development of the CNS.

In the present study, examination of APC mRNA expression during postnatal development revealed that APC expression is maintained at high levels until the late stages of maturation of neuronal connections and morphology. However, our results suggest that APC expression declines prior to completion of this process. For example, in striatum, APC mRNA levels decline substantially by P10, even though marked increases in synaptic density occur between P13 and P17 in this region (Hattori and McGeer, 1973). The reduction in APC expression toward the final stages of neuronal maturation coincides with the transition to adult patterns of expression of several other genes. For example, expression of APC mRNA in the cortex remains high until P15 and then declines. This temporal pattern parallels the

Figure 13. APC mRNA expression in the hippocampus. Dark-field photomicrographs of emulsion-dipped sections following hybridization with APC or NMDAR1 antisense riboprobes are shown. The top left panel shows the pattern of APC hybridization at P20; for comparison, the top right panel shows the adjacent section hybridized with an NMDAR1. The bottom left is the APC pattern at P30; the bottom right shows the APC pattern of APC mRNA expression in the adult. alv, alveus; $m f$, mossy fiber; $D G$, dentate gyrus; $C A 1$, field of hippocampus. Asterisk indicates the external medullary layer, a fiber tract in the thalamus; arrow indicates mossy fibers; and arrowheads indicate alveus fiber tract. Exposure time, $5 \mathrm{~d}$. 

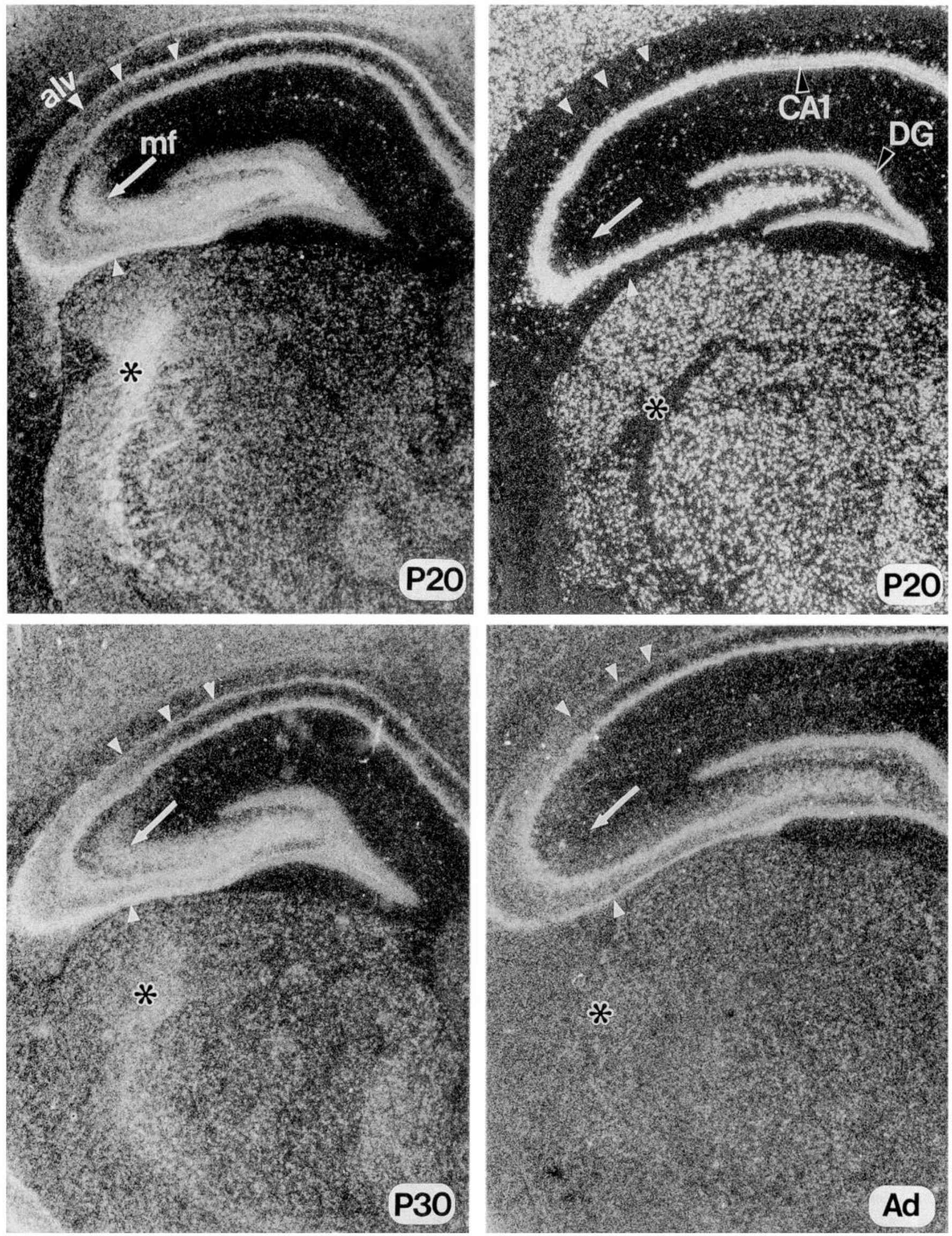
switch in expression of isoforms of microtubule-associated protein-2 (MAP2), which is thought to reflect maturation of the dendritic cytoskeleton (Riederer and Matus, 1985; Matus, 1988; Tucker, 1990). Expression of dynamin-1, another microtubuleassociated protein thought to function as a motor protein, is also induced at the time APC mRNA expression is downregulated (Faire et al., 1992). In contrast to other brain regions, APC mRNA expression is not diminished in adulthood in the olfactory bulb. This persistent high level of expression in the olfactory bulb may reflect the substantial neuronal proliferation that continues in this area in the adult rat (Altman, 1969; Bayer, 1983; Kaplan et al., 1985; O'Leary, 1993). Interestingly, the forms of MAP2 and several other microtubule-associated proteins found in early development persist in adult olfactory bulb (Viereck et al., 1989).

Analysis of APC expression during development of the hippocampus and thalamus revealed prominent hybridization associated with several fiber tracts, such as the alveus, in addition to neuronal cell bodies. This expression was developmentally regulated, as high levels apparent during early postnatal life decline by 6 weeks of age. In the adult, expression persisted at reduced levels in the alveus. Examination of these areas with a probe to the NMDAR 1 subunit, which appears to label neuronal cell bodies (Moriyoshi et al., 1991), indicates that the pattern of APC hybridization does not merely reflect expression in neuronal cell bodies in these layers. Accordingly, this pattern could reflect APC mRNA localization in axons. A few examples of mRNA localization outside neuronal cell bodies have been reported in either dendrites (Bruckenstein, 1990; Kleiman et al., 1990) or axons (Litman et al., 1993), so this possibility needs to be considered. Alternatively, APC mRNA could be expressed in glial elements in these layers. Supporting this possibility is the presence of aggregates of presumed glial cells in the alveus and thalamic tracts when dense APC hybridization is observed. Studies of glial cell differentiation in the optic nerve revealed that maturation of cells in the oligodendrocyte lineage continues during the first few weeks of postnatal life (Raff, 1989). Thus, it is tempting to spcculate that APC mRNA expression in these tracts could reflect induction of APC in glia that are withdrawing from the cell cycle during maturation of these fiber tracts. Conceivably, the prominent APC expression seen in a restricted group of white matter tracts may reflect differences in the process of glial cell differentiation among white matter tracts.

In summary, we have characterized the expression of APC mRNA in the CNS during development. On the basis of the pattern observed, we suggest that a rise in APC expression occurs as postmitotic neurons are generated and its decline coincides with the switch to a mature neuronal cytoskeleton. During this period of prominent APC expression, neurons undergo extensive morphological changes associated with process extension and synapse formation. Perhaps the APC gene acts to suppress reentry into the cell cycle in these postmitotic neurons during this interval of intense growth. As our results indicate that APC is expressed abundantly in the developing CNS, progress in defining the cellular function of the APC gene will likely provide important insights into neuronal development.

\section{References}

Altman J (1969) Autoradiographic and histological studies of postnatal neurogenesis. IV. Cell proliferation and migration in the anterior forebrain, with special reference persisting neurogenesis in the olfactory bulb. J Comp Neurol 137:433-458.
Altman J (1972) Postnatal development of the cerebellar cortex in the rat. I. The external germinal layer and the transitional molecular layer. J Comp Neurol 145:399-464.

Angevine JB, Sidman RL (1961) Autoradiographic study of cell migration during histogenesis of cerebral cortex in the mouse. Nature 192:766-768.

Baycr SA (1983) ${ }^{3} \mathrm{H}$-thymidine-radiographic studies of neurogenesis in the rat olfactory bulb. Exp Brain Res 50:329-340.

Berry M, Rogers AW (1965) The migration of neuroblasts in the developing cerebral cortex. J Anat 99:691-709.

Bhat RV, Cole A, Baraban JM (1992) Chronic cocaine treatment suppresses basal expression of zif 268 in rat forebrain: in situ hybridization studies. J Pharmacol Exp Ther 263:343-349.

Bloomquist BT, Eipper BA, Mains RE (1991) Prohormone converting enzymes: regulation and evaluation of function using antisense RNA. Mol Endocrinol 5:2014-2024.

Bruckenstein DA, Lein PJ, Higgins D, Fremeau RT Jr (1990) Distinct spatial localization of specific mRNAs in cultured sympathetic neurons. Neuron 5:809-819.

Burgoyne RD, Cambray-Deakin MA (1988) The cellular neurobiology of neuronal development. The cerebellar granule cell. Brain Res Rev 13:77-101.

Clarke AR, Purdie CA, Harrison DJ, Morris RG, Bird CC, Hooper ML, Wyllie AH (1993) Thymocyte apoptosis induced by p53-dependent and independent pathways. Nature 362:849-852.

Crail HW (1949) Multiple primary malignancies arising in the rectum, brain and thyroid. US Naval Med Bull 49:123-128.

Faire K, Trent F, Tepper JM, Bouder EM (1992) Analysis of dynamin isoforms in mammalian brain: dynamin-1 expression is spatially and temporally regulated during postnatal development. Proc Natl Acad Sci USA 89:8376-8380.

Fujita S, Shimada M, Nakanuna T (1966) ${ }^{3} \mathrm{H}$-thymidine autoradiographic studies on the cell proliferation and differentiation in the external and internal granular layers of the mouse cerebellum. J Comp Ncurol 128:191-209.

Groden J, Thliveris A, Samowitz W, Carlson M, Gelbert L, Albertsen H, Joslyn G, Stevens J, Spirio L, Robertson M, Sargeant L, Krapcho $\mathrm{K}$, WolffE, Burt R, Hughes JP, Warrington J, McPherson J, Wasmuth J, Le Paslier D, Abderrahim H, Cohen D, Leppert M, White R (1991) Identification and characterization of the familial adenomatous polyposis coli gene. Cell 66:589-600.

Hattori T, McGeer PL (1973) Synaptogenesis in the corpus striatum of infant rat. Exp Neurol 38:70-79.

Herrera L, Kakati S, Gibas L, Pietrzak E, Sandbert A (1986) Brief clinical report: Gardner syndrome in a man with an interstitial deletion of 5q. Am J Med Genet 25:473-476.

Jacobson M (1978) Developmental neurobiology, pp 83-88. New York: Plenum.

Joslyn G, Carlson M, Thliveris A, Albcrtscn H, Gelbert L, Samowitz W, Groden J, Stevens J, Spirio L, Robertson M, Sargeant L, Krapcho K, Wolff E, Burt R, Hughes JP, Warrington J, McPherson J, Wasmuth J, Le Paslier D, Abderrahim H, Cohen D, Leppert M, White R (1991) Identification of deletion mutations and three new genes at the familial polyposis locus. Cell 66:601-613

Kaplan MS, McNelly NA, Hinds JW (1985) Population dynamics of adult-formed granule neurons of the rat olfactory bulb. J Comp Neurol 239:117-125.

Kinzler KW, Nilbert MC, Su L-K, Vogelstein B, Bryan TM, Levy DB, Smith KJ, Preisinger AC, Hedge P, McKechnie D, Finniear R, Markham A, Groffen J, Boguski MS, Altschul SF, Horii A, Ando $\mathrm{H}$, Miyoshi Y, Miki Y, Nishiho I, Nakamura Y (1991) Identification of FAP locus genes from chromosome $5 \mathrm{q} 21$. Science 253:661-665.

Kleiman R, Banker G, Steward O (1990) Differential subcellular localization of particular mRNAs in hippocampal neurons in culture. Neuron 5:821-830.

Klein CT (1987) The approaching era of the tumor suppressor genes. Science 238:1539-1545.

Konig N, Marty R (1981) Early neurogenesis and synaptogenesis in cerebral cortex. Bibl Anat 19:152-160.

Kropilak M, Jagelman DG, Fazio VW, Lavery IL, McGannon E (1989) Brain tumors in familial adenomatous polyposis. Dis Colon Rectum 32:778-782.

Lawlor KG, Narayanan R (1992) Persistent expression of the tumor suppressor gene DCC is essential for neuronal differentiation. Cell Growth Differ 3:609-616.

Lee EY-HP, Chang C-Y, Hu N, Wang Y-CJ, Lai C-C, Herrup K, Lee 
W-II, Bradley A (1992) Mice deficient for $\mathrm{Rb}$ are nonviable and show defects in neurogenesis and haematopoiesis. Nature 359:288294.

Litman P, Barg J, Rindzoonski L, Ginzburg I (1993) Subcellular localization of tau mRNA in differentiating neuronal cell culture: implications for neuronal polarity. Neuron 10:627-638.

Lowe SW, Schmitt EM, Smith SW, Osborne BA, Jacks T (1993) p53 is required for radiation-induced apoptosis in mouse thymocytes. Nature 362:847-849.

Marin-Padilla M (1971) Early prenatal ontogenesis of the cerebral cortex (neocortex) of the cat (Felis domestica). A Golgi study. 1. The primordial neocortical organization. Z Anat Entwicklungsgesch 134: $117-145$.

Matus A (1988) Microtubule-associated proteins and neuronal morphogenesis. Annu Rev Neurosci 11:29-44.

Miale I, Sidman RL (1961) An autoradiographic analysis histogenesis in the mouse cerebellum. Exp Neurol 4:277-296.

Miyoshi $Y$, Ando M, Nagase M, Nishisho I, Morii A, Miki Y, Mori T, Utsunomiya J, Baba S, Peterson G, Hamilton SR, Kinzler KW, Vogelstein B, Nakamura Y (1992) Germ-line mutations of the APC gene in 53 familial adenomatous polyposis patients. Proc Natl Acad Sci USA 89:4452-4456.

Morest DK (1970) The pattern of neurogenesis in the retina of the rat. Z Anat Entwicklungsgesch 131:45-67.

Moriyoshi K, Masu M, Ishii T, Shigemoto R, Mizuno N, Nakanishi S (1991) Molecular cloning and characterization of the rat NMDA receptor. Nature 354:31-37.

Nishisho I, Nakamura Y, Miyoshi Y, Miki Y, Ando H, Horii A, Koyama K, Utsunomiya J, Baba S, Hedge P, Markham A, Krush AJ, Petersen G, Hamiltón SR, Nilbert MC, Levy DB, Bryan TM, Preisinger AC, Smith KJ, Su L-K, Kinzler KW, Vogelstein B (1991) Mutations of chromosome $5 \mathrm{q} 21$ genes in FAP and colorectal cancer patients. Science 253:665-669.

O'Leary DDM (1993) Adding neurons to the adult mammalian brain Proc Natl Acad Sci USA 90:2101-2102.

Oppenheim RW, Prevette D, Tytell M, Homma S (1990) Naturally occurring and induced neuronal death in the chick embryo in vivo requires protein and RNA synthesis: evidence for the role of cell death genes. Dev Biol 138:104-113.

Paxinos G, Watson C (1982) The rat brain, in stereotaxic coordinates. New York: Academic.

Paxinos G, Tork I, Tecott LH, Valentino KL (1991) Atlas of the developing rat brain. San Diego: Academic.

Powell SM, Zilz N, Beazer-Barclay Y, Bryan TM, Hamilton SR, Thibodeau SN, Vogelstein B, Kinzler KW (1992) APC mutations occur early during colorectal tumorigenesis. Nature 359:235-237.
Raff MC (1989) Glial cell diversification in the rat optic nerve. Science 243:1450-1455.

Rakic P (1972) Mode of cell migration in the superficial layers of fetal monkey neocortex. J Comp Neurol 145:61-84.

Riederer B, Matus A (1985) Differential expression of distinct microtubule-associated proteins during brain development. Proc Natl Acad Sci USA 82:6006-6009.

Sager R (1989) Tumor suppressor genes: the puzzle and the promise. Science 246:1406-1412.

Sambrook J, Fritsch EF, Maniatis T (1989) Molecular cloning, a laboratory manual, pp 9.50-9.51. Cold Spring Harbor, NY: Cold Spring Harbor Laboratory.

Smith KJ, Johnson KA, Bryan TM, Hill DE, Markowitz S, Willson JKV, Paraskeva C, Petersen GM, Hamilton SR, Vogelstein B, Kinzler KW (1993) The APC gene product in nomal and tumor cells. Proc Natl Acad Sci USA 90:2846-2850.

Sohrabi AK, Phillips J, Watne AL (1991) Gynecological malignancies, brain tumors and familial adenomatous polyposis. J Surg Oncol 47 203-205.

Stoffers DA, Green CBR, Eipper BA (1989) Alternative mRNA splicing generates multiple forms of peptidyl-glycine $\alpha$-amidating monooxygenase in rat atrium. Proc Natl Acad Sci USA 86:735-739.

Su L-K, Kinzler KW, Vogelstein B, Preisinger AC, Moser AR, Luongo C, Gould KA, Dove WF (1992) Multiple intestinal neoplasia caused by a mutation in the murine homolog of the APC gene. Science 256 : $668-670$.

Tamkun MM, Knoth KM, Walbridge JA, Kroemer H, Roden DM, Glover DM (1991) Molecular cloning and characterization of two voltage-gated $\mathrm{K}^{+}$channel cDNAs from human ventricle. FASEB J 5:331-337.

Tucker RP (1990) The roles of microtubule-associated proteins in brain morphogenesis: a review. Brain Kes Kev 15:101-120.

Turcot J, Despres J-P, St Pierre F (1959) Malignant tumors of the central nervous system associated with familial polyposis of the colon: report of two cases. Dis Colon Rectum 2:465-468.

Viereck C, Tucker RP, Matus A (1989) The adult rat olfactory system expresses microtubule-associated proteins found in the develnping brain. J Neurosci 9:3547-3557.

Vogelstein B, Kinzler KW (1993) The multistep nature of cancer. Trends Genet 9:138-141.

Weinberg RA (1991) Tumor suppressor genes. Science 254:1138-1146

Yoon J, Shortridge RD, Bloomquist BT, Schneuwly S, Perdew MH, Pak WL (1989) Molecular characterization of Drosophila yene encoding $\mathrm{G}_{\mathrm{o}} \alpha$ subunit homolog. J Biol Chem 264:18536-18543. 